\title{
Economic impact of inhibitors in pediatric hemophilia A
}

Araceli López-Facundo, ${ }^{1}$ Cecilia Rodríguez-Castillejos, ${ }^{1}$ Yulia Romero, ${ }^{2}$ Juan Gay ${ }^{3}$ and Diddier Prada ${ }^{1}$ Instituto de Seguridad Social del Estado de México y Municipios, Mother-Child Hospital, State of Mexico; '2Zeed Pharmaceutical Solutions, Clinical Operations, Mexico City; ${ }^{3}$ Technology and Information for Health, Mexico City; ${ }^{4}$ Instituto Nacional de Cancerología, Mexico City. Mexico

\begin{abstract}
\end{abstract}
Introduction: Few studies have assessed the economic impact of inhibitors in hemophilia A in Mexico, especially in the pediatric population. Objective: To determine the economic impact entailed by the development of inhibitors in pediatric patients with hemophilia A. Method: Patients with hemophilia A under the care of a pediatric hematology department between December 2015 and November 2017 were retrospectively assessed. Direct and indirect costs were determined based on the presênce or absence of inhibitors. Results: The cost analysis of the study population $(n=24)$ showed that diagnosis, follow-up, prophylaxis, treatment and hospitalization of these patients had an annual cost of \$ 6883187.4 per patient, out of which morecthan $95 \%$ depended on the use of hemostatic factors. Annual cost per patient in the group with inhibitors was \$5 548765.0 in comparison with \$1334 422.4 in the group without inhibitors, 4.2 times higher. Conclusions: This is the first national study to show that the presence of inhibitors in pediatric patients with hemophilia $A$ increases the cost of the disease more than four times.

KEY WORDS: Economic impact. Annual cost. Hemophilia A. Inhibitors. Mexico

\section{Introduction}

Hemophilia is a rare congenital disease, characterized by genetic abnormalities that cause factor VIII (hemophilia A) or factor IX (hemophilia type B) functional loss. ${ }^{1}$ The prevalence of hemophilia $A$ is estimated at approximately one case per 5000 to 7000 male births. ${ }^{2}$ Patients with type A or B hemophilia, especially in the severe clinical form, experience repeated spontaneous or posttraumatic prolonged bleeding. ${ }^{3}$ Prophylaxis, especially if started early in the course of life, has been associated with better joint outcomes. ${ }^{4}$ Patients with hemophilia A can develop antibodies that neutralize the coagulation factor VIII they are administered. ${ }^{3}$ Currently, treatment cost is one of the most important aspects to consider in this disease, ${ }^{5}$ however, in our country there are few studies that have carried out a cost analysis. ${ }^{6}$
This research aimed to determine the direct and indirect costs of hemophilia A management, with an emphasis on the development of inhibitors.

\section{Method}

This study was carried out retrospectively at the Mother-Child Hospital of the Institute of Social Security of the State of Mexico and Municipalities, Toluca unit, in Mexico. All pediatric patients with hemophilia A who were provided care between December 2015 and November $2017(n=24)$ were assessed. 常 study was approved by the Institutional Ethics Committee of the hospital. A thorough recording of patient sociodemographic and clinical characteristics and bleeding events was carried out, including the type of administered factor, consultations required, laboratory tests, imaging studies and coagulation factor determinations, among others.
Date of reception: 10-09-2018

Date of acceptance: 17-05-2019

DOI: 10.24875/GMM.M19000300
Gac Med Mex. 2019;155:34t/2347

Contents available at PubMed www.gacetamedicademexice.com 
Table 1. Heredofamilial and clinical characteristics of pediatric patients with hemophilia $\mathbf{A}^{\text {* }}$

\begin{tabular}{|c|c|c|c|c|c|}
\hline \multirow{2}{*}{$\begin{array}{l}\text { Variables } \\
\text { Continuous }\end{array}$} & \multicolumn{2}{|c|}{$\begin{array}{l}\text { Without inhibitors } \\
\qquad(\mathrm{n}=19)\end{array}$} & \multicolumn{2}{|c|}{$\begin{array}{l}\text { With inhibitors } \\
\qquad(\mathrm{n}=5)\end{array}$} & \multirow{2}{*}{$\overbrace{\frac{\mathrm{C}}{\mathrm{D}}}^{0}$} \\
\hline & Mean/Median* & SD/IQR & Mean/Median* & SD/IQR & \\
\hline Age at diagnosis (months) & 16.00 & 28.00 & 9.50 & 7.50 & $0.34 \underline{6}$ \\
\hline Age at the time of the study (years) & 11.64 & 3.72 & 9.67 & 3.74 & 0.060 \\
\hline Factor VIII at diagnosis (\%) & 0.03 & 0.02 & 0.03 & 0.03 & 0.996 \\
\hline First recorded factor VIII (\%) & 0.01 & 0.03 & 0.04 & 0.41 & 0.354 \\
\hline Number of affected relatives & 3.00 & 3.50 & 2.00 & 0.00 & 0.717 \\
\hline Categorical & $\mathrm{n}$ & $\%$ & n & $\%$ & $\frac{1}{t}$ \\
\hline $\begin{array}{l}\text { Gender } \\
\text { Males }\end{array}$ & 19 & 100.0 & 5 & 100.0 & $\begin{array}{l}\frac{1}{0} \\
\frac{1}{0}\end{array}$ \\
\hline $\begin{array}{l}\text { Severity at diagnosis } \\
\text { Mild } \\
\text { Moderate } \\
\text { Severe }\end{array}$ & $\begin{array}{c}2 \\
10 \\
7\end{array}$ & $\begin{array}{l}10.5 \\
52.6 \\
36.8\end{array}$ & $\begin{array}{l}0 \\
4 \\
1\end{array}$ & $\begin{array}{c}0.0 \\
80.0 \\
20.0\end{array}$ & $\frac{0.50 . \frac{4}{\varepsilon}}{\frac{\varepsilon}{\frac{\delta}{d}}}$ \\
\hline $\begin{array}{l}\text { Received home treatment } \\
\text { Yes } \\
\text { No }\end{array}$ & $\begin{array}{c}9 \\
10\end{array}$ & $\begin{array}{l}47.4 \\
52.6\end{array}$ & $\begin{array}{l}2 \\
3\end{array}$ & $\begin{array}{l}40.0 \\
60.0\end{array}$ & 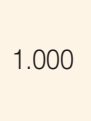 \\
\hline $\begin{array}{l}\text { Home treatment** } \\
\text { Factor VII } \\
\text { Factor VIII } \\
\text { No data** }^{\star *}\end{array}$ & $\begin{array}{c}0 \\
10 \\
9\end{array}$ & $\begin{array}{c}0.0 \\
100.0\end{array}$ & $\begin{array}{l}2 \\
1 \\
2\end{array}$ & $\begin{array}{l}66.7 \\
33.3\end{array}$ & 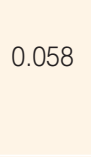 \\
\hline $\begin{array}{l}\text { Target joint (previous) }{ }^{* *} \\
\text { No } \\
\text { Yes } \\
\text { No data** }\end{array}$ & $\begin{array}{l}14 \\
4 \\
1\end{array}$ & $\begin{array}{l}77.8 \\
22.2\end{array}$ & $\begin{array}{l}5 \\
0\end{array}$ & $\begin{array}{c}100.0 \\
0.0\end{array}$ & 0.62 \\
\hline $\begin{array}{l}\text { Depending on the normality of the variable. Moth } \\
{ }^{*} \text { Not included in frequency distribution. }\end{array}$ & $\begin{array}{l}\text { ital, Institute of Social S } \\
\text { at least three times in }\end{array}$ & $\begin{array}{l}\text { the State of } 1 \\
\text { of } 1 \text { to } 3 \text { mont }\end{array}$ & d Municipalities, Toluc & Der 2015 to NC & 2017. ". \\
\hline
\end{tabular}

For direct cost analysis (those derived from the care of the disease), the year 2016 was taken as the basis, considering institutional costs for that year, with the calculation being carried out in Mexican pesos. For indirect costs (those that do not directly depend on the underlying disease) averages of income per worked hour and hours worked per week in the employed population during 2016 for Mexico, as determined by the National Institute of Statistics and Geography, including lost days due to hospitalization and the days used for care in the visits required during the study period by patient parents or legal guardians. ${ }^{7,8}$ Data were analyzed with the $\mathrm{R}^{\circledR}$ software (R Project for Statistical Computing, CRAN, The Comprehensive R Archive Network, Vienna).

\section{Results}

Patient family, hereditary and clinical characteristics, both in patients with and without inhibitors, are shown in Table 1. Details of the hemorrhagic events are shown in Table 2.

\section{Direct costs}

The cost for medical appointments per patient year in the group without inhibitors was $\$ 757.1$ (0.06 \% of total annual cost per patient), in comparison with $\$ 548.0$ in the group with inhibitors $(0.01 \%)$. Regarding laboratory tests, the estimated cost per patient per fyear for this item was $\$ 357.0$ in the subgroup without inhibitors ( $0.03 \%$ of total annual cost per patient) and \$131.8 in the subgroup with inhibitors $(0.01 \%)$. Regardingimaging studies, the estimated cost for this item per patient per year was $\$ 722.4$ (0.05\% of total annual cost-per patient) in the group without inhibitors, in comparison with \$ $669.5(0.05 \%)$ in the group with inhibitors. T् The detailed cost of medical appointments, with the recorded laboratory and imaging tests, are shown in Table 3? 
Table 2. Hemorrhagic events in pediatric patients with hemophilia $\mathbf{A}^{\ddagger}$

\begin{tabular}{|c|c|c|c|c|c|c|c|}
\hline \multirow[t]{2}{*}{ Characteristics } & \multicolumn{3}{|c|}{ Without inhibitors $(n=19)$} & \multicolumn{3}{|c|}{ With inhibitors $(n=5)$} & \multirow{2}{*}{ To } \\
\hline & $\begin{array}{c}\text { Events } \\
\text { (n) }\end{array}$ & $\%$ & $\begin{array}{l}\text { Events per } \\
\text { patient } \\
\text { (n) }\end{array}$ & $\begin{array}{c}\text { Events } \\
\text { (n) }\end{array}$ & $\%$ & $\begin{array}{c}\text { Events per } \\
\text { patient } \\
\text { (n) }\end{array}$ & \\
\hline $\begin{array}{l}\text { Type of bleeding } \\
\text { Articular } \\
\text { Mucosal } \\
\text { Muscular } \\
\text { Traumatic brain injury } \\
\text { Hemorrhage due to direct trauma } \\
\text { No data } \\
\text { Subtotal }\end{array}$ & $\begin{array}{c}73 \\
26 \\
8 \\
4 \\
1 \\
1 \\
113\end{array}$ & $\begin{array}{c}64.60 \\
23.01 \\
7.08 \\
3.54 \\
0.88 \\
0.88 \\
100.00\end{array}$ & $\begin{array}{l}3.84 \\
1.37 \\
0.42 \\
0.21 \\
0.05 \\
0.05 \\
5.95\end{array}$ & $\begin{array}{c}21 \\
5 \\
2 \\
0 \\
0 \\
0 \\
28\end{array}$ & $\begin{array}{c}75.00 \\
17.86 \\
7.14 \\
0.00 \\
0.00 \\
0.00 \\
100.00\end{array}$ & $\begin{array}{l}4.20 \\
1.00 \\
0.40 \\
0.00 \\
0.00 \\
0.00 \\
5.60\end{array}$ & \\
\hline $\begin{array}{l}\text { Anatomical site } \\
\text { Lower limbs } \\
\text { Upper limbs } \\
\text { Mucosal } \\
\text { Muscular } \\
\text { Unknown } \\
\text { Central Nervous System } \\
\text { Other } \\
\text { Subtotal }\end{array}$ & $\begin{array}{c}41 \\
28 \\
27 \\
6 \\
6 \\
2 \\
3 \\
113\end{array}$ & $\begin{array}{c}36.28 \\
24.78 \\
23.89 \\
5.31 \\
5.31 \\
1.77 \\
2.65 \\
100.00\end{array}$ & $\begin{array}{l}2.16 \\
1.47 \\
1.42 \\
0.32 \\
0.32 \\
0.11 \\
0.16 \\
5.95\end{array}$ & $\begin{array}{l}12 \\
8 \\
5 \\
1 \\
0 \\
0 \\
2 \\
28\end{array}$ & $\begin{array}{l}42.86 \\
28.57 \\
17.86 \\
3.57 \\
0.00 \\
0.00 \\
7.14 \\
100.00\end{array}$ & $\begin{array}{l}2.40 \\
1.60 \\
1.00 \\
0.20 \\
0.00 \\
0.00 \\
0.40 \\
5.60\end{array}$ & \\
\hline $\begin{array}{l}\text { Patients with target joint* } \\
\text { Yes } \\
\text { No } \\
\text { Subtotal }\end{array}$ & $\begin{array}{c}4 \\
15 \\
19\end{array}$ & $\begin{array}{c}83.34 \\
16.66 \\
100.00\end{array}$ & $\begin{array}{l}0.21 \\
0.79 \\
1.00\end{array}$ & $\begin{array}{l}0 \\
5 \\
5\end{array}$ & $\begin{array}{c}79.17 \\
20.83 \\
100.00\end{array}$ & $\begin{array}{l}0.00 \\
1.00 \\
1.00\end{array}$ & \\
\hline $\begin{array}{l}\text { Hemorrhagic events that received hemostatic factor** } \\
\text { Yes } \\
\text { No } \\
\text { No data } \\
\text { Subtotal }\end{array}$ & $\begin{array}{c}101 \\
3 \\
9 \\
113\end{array}$ & $\begin{array}{c}89.38 \\
2.65 \\
7.96 \\
100.00\end{array}$ & $\begin{array}{l}5.32 \\
0.16 \\
0.47 \\
5.95\end{array}$ & $\begin{array}{c}28 \\
0 \\
0 \\
28\end{array}$ & $\begin{array}{c}100 \\
0.0 \\
0.0 \\
100.00\end{array}$ & $\begin{array}{l}5.60 \\
0.00 \\
0.00 \\
5.60\end{array}$ & \\
\hline $\begin{array}{l}\text { ₹Mother-Child Hospital, Institute of Social Security of the State of Mexico ar } \\
{ }^{*} \text { Defined as the presence of a joint that bleeds at least thrice in a period o } \\
{ }^{*} \text { Number of factor VIII administrations in the study period and in all evalua } \\
\text { Security of the State of Mexico and Municipalities. }\end{array}$ & $\begin{array}{l}\text { d Municipalit } \\
1 \text { to } 3 \text { month } \\
\text { ed patients. }\end{array}$ & Oluca, Dec & $\begin{array}{l}\text { oer } 2015 \text { to No } \\
\text { de Seguridad }\end{array}$ & er 2017. & México y & unicipios) = Insti & \\
\hline
\end{tabular}

\section{HEMOSTATIC FACTOR CONSUMPTION FOR PROPHYLAXIS AND BLEEDING EVENTS}

Annual cost per patient for the use of factor VIII for prophylaxis was $\$ 1,141,240.9$ (85.52\% of total annual cost per patient) in the group without inhibitors and $\$ 1,783,375.2(32.12 \%)$ in the group with inhibitors. Prophylaxis annual cost, including factors VII and VIII, was $\$ 36,407,522.3$, with an annual cost of $\$ 1,141,240.9$ per patient for the group without inhibitors, in comparison with $\$ 2,944,788.9$ in the group with inhibitors, which represents a 2.6 -fold higher cost for prophylaxis associated with the presence of inhibitors. The cost for the use of hemostatic factors for prophylaxis, detailed by patient and throughout the study period, is shown in Table 4.

Annual cost per patient for the use of factor VIII for the care of hemorrhagic events was $\$ 187,851.0(14.08 \%$ of total annual cost per patient) in the group without inhibitors and $\$ 37,422.0(0.67 \%)$ in the group with inhibitors. The cost of using factor VIII for the care of hemorrhagic events, detailed by patient, as well asthe cost throughout the study period and individual anñual cost are shown in Table 5. Annual cost per patient for the use of Factor VII as prophylaxis was $\$ 1,161,413.7$ (20.92\% of total annual cost per patiênt) and for the care of hemorrhagic events, \$2,560 105.4 in the group with inhibitors $(46.11 \%)$. Factor VII was not administered to patients without inhibitors.

\section{IN-HOSPITAL CARE}

The percentages of in-hospital care events, reason for hospitalization and factor VIII requirements for each group (without and with inhibitors) are shown in Table 6 .

\section{Indirect costs}

Two-hundred and sixty days lost by the cohort were quantified. Annual cost per patient for the days of work 
Table 3. Resources consumed by pediatric patients with hemophilia * $^{*}$

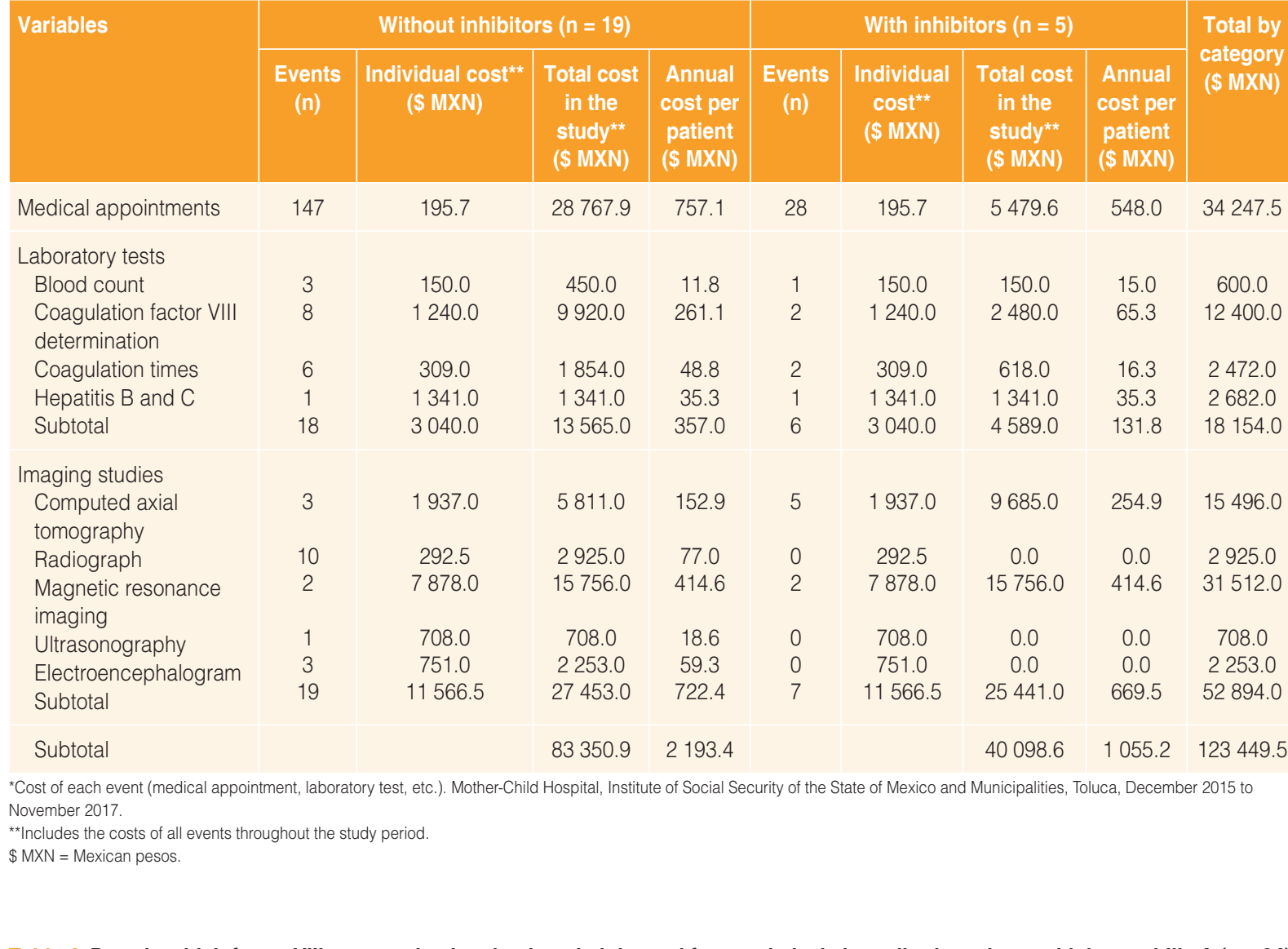

Table 4. Days in which factor VIII was received and units administered for prophylaxis in pediatric patients with hemophilia $A(n=24)^{*}$

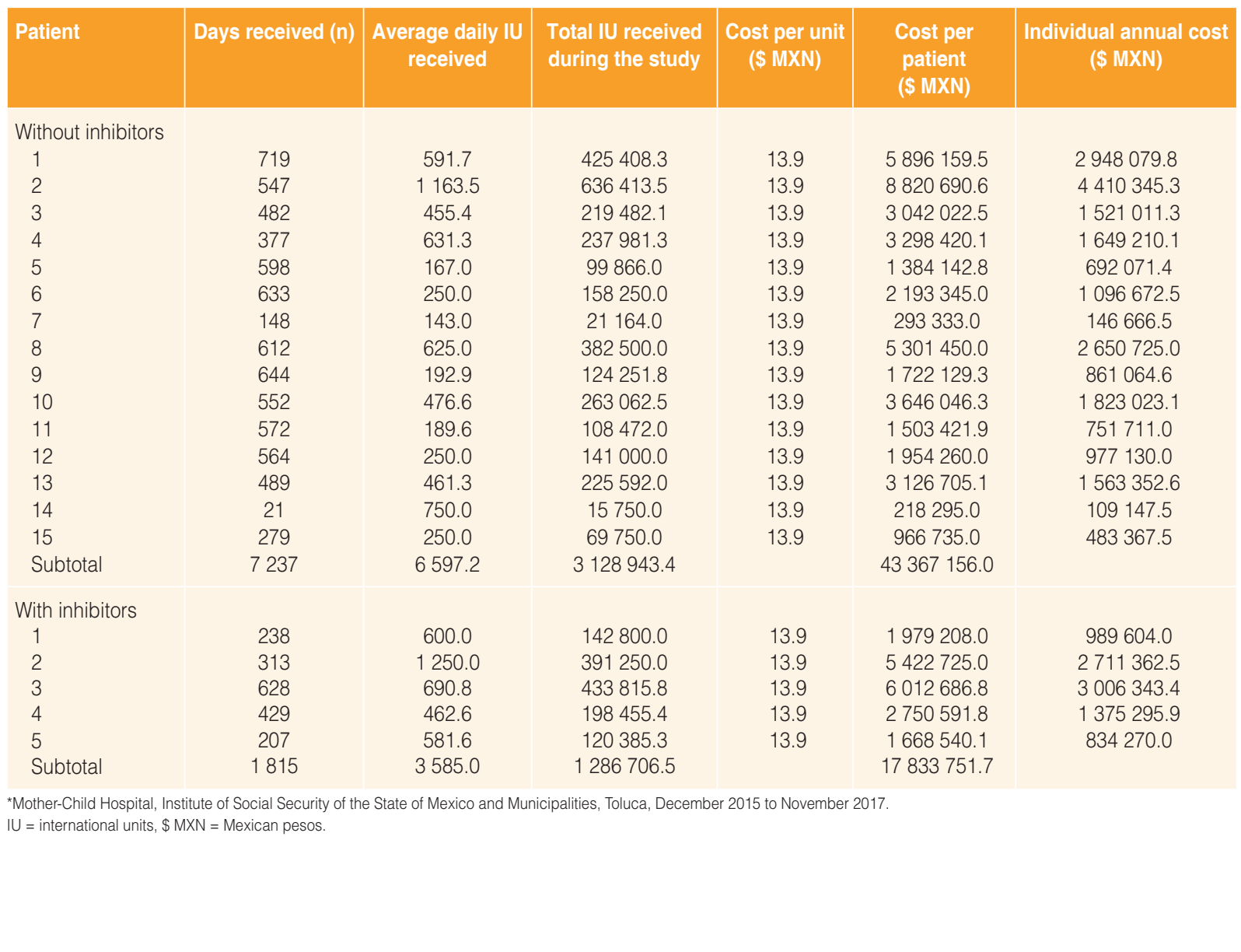


López-Facundo A, et al.: Cost of hemophilia with inhipitors

Table 5. Days in which factor VIII was received and administered units for the care of hemorrhagic events in pediatric patients with hemophilia $A(n=24)^{*}$

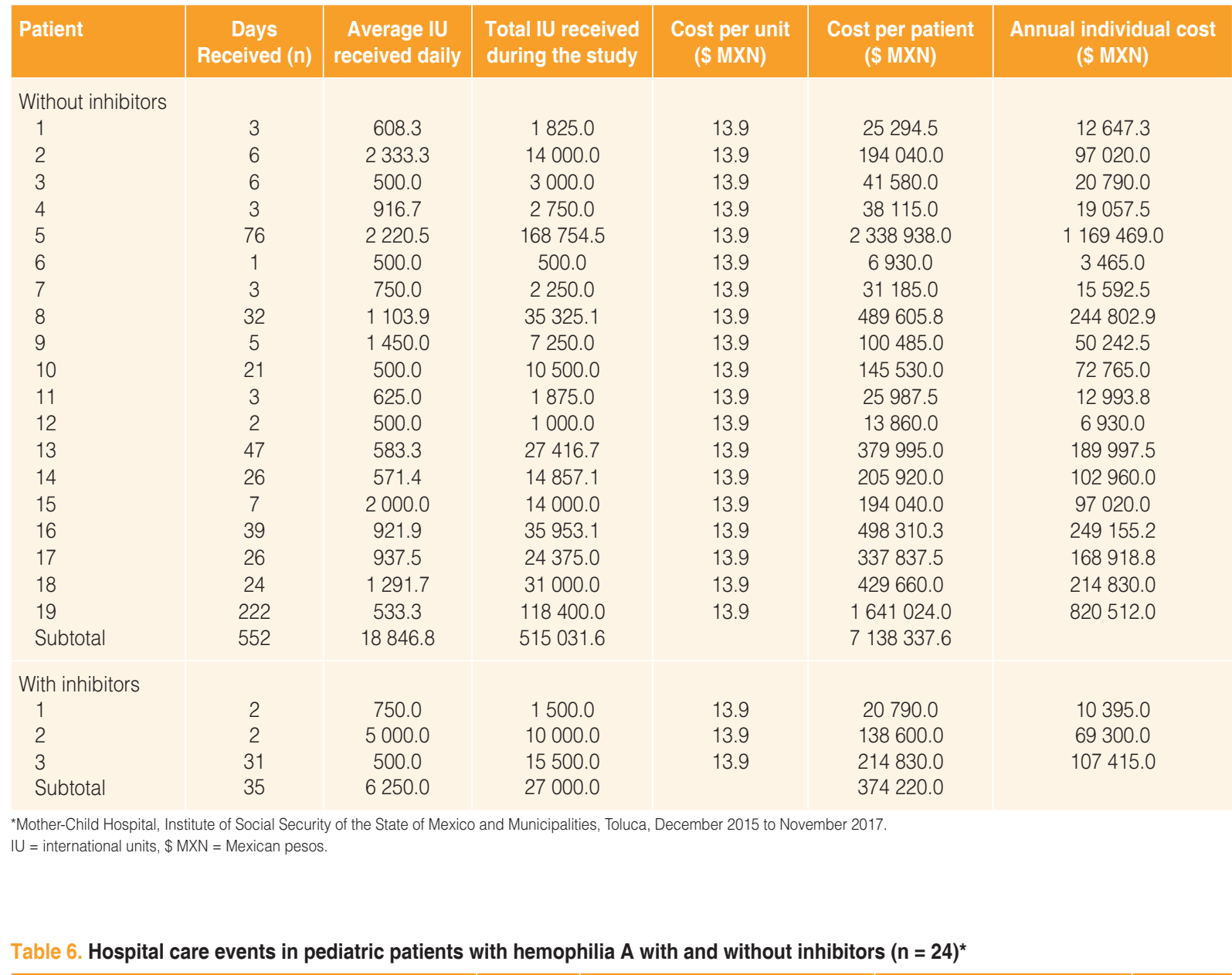

\begin{tabular}{|c|c|c|c|c|c|c|}
\hline \multirow[t]{2}{*}{ Events } & \multirow{2}{*}{$\begin{array}{l}\text { Total } \\
\text { (n) }\end{array}$} & \multicolumn{2}{|c|}{ Without inhibitors $(n=19)$} & \multicolumn{2}{|c|}{ With inhibitors $(n=5)$} & \multirow{2}{*}{ 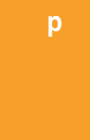 } \\
\hline & & $\begin{array}{l}\text { Events } \\
\text { (n) }\end{array}$ & $\%^{* *}$ & $\begin{array}{c}\text { Events } \\
\text { (n) }\end{array}$ & $\% * *$ & \\
\hline Hospital care events & 59 & 46 & 100.00 & 13 & 100.00 & 0 \\
\hline $\begin{array}{l}\text { Visit to the emergency department } \\
\text { Care at emergency room without hospitalization } \\
\text { Care at emergency room with hospitalization } \\
\text { Hospitalization by hematology department }\end{array}$ & $\begin{array}{c}49 \\
33 \\
9 \\
7\end{array}$ & $\begin{array}{c}37 \\
28 \\
4 \\
5\end{array}$ & $\begin{array}{l}75.68 \\
10.81 \\
13.51\end{array}$ & $\begin{array}{l}12 \\
5 \\
5 \\
2\end{array}$ & $\begin{array}{l}41.67 \\
41.67 \\
16.67\end{array}$ & 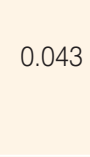 \\
\hline $\begin{array}{l}\text { Reason for hospitalization } \\
\text { Prophylaxis } \\
\text { Hemorrhage } \\
\text { Infection } \\
\text { Trauma } \\
\text { Surgery } \\
\text { Other } \\
\text { Unknown }\end{array}$ & $\begin{array}{c}22 \\
10 \\
5 \\
2 \\
1 \\
8 \\
11\end{array}$ & $\begin{array}{c}22 \\
1 \\
5 \\
2 \\
1 \\
5 \\
10\end{array}$ & $\begin{array}{c}47.83 \\
2.17 \\
10.87 \\
4.35 \\
2.17 \\
10.87 \\
21.74\end{array}$ & $\begin{array}{l}0 \\
9 \\
1 \\
0 \\
0 \\
2 \\
1\end{array}$ & $\begin{array}{c}0.00 \\
69.23 \\
7.69 \\
0.00 \\
0.00 \\
15.38 \\
7.69\end{array}$ & 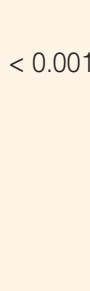 \\
\hline $\begin{array}{l}\text { Need for factor VIII during hospitalization } \\
\text { Yes } \\
\text { No } \\
\text { Unknown }\end{array}$ & $\begin{array}{l}35 \\
13 \\
11\end{array}$ & $\begin{array}{c}30 \\
6 \\
10\end{array}$ & $\begin{array}{l}83.33 \\
16.67\end{array}$ & $\begin{array}{l}5 \\
7 \\
1\end{array}$ & $\begin{array}{l}41.67 \\
58.33\end{array}$ & $0.0 \frac{\pi 48}{+\frac{\pi}{+}}$ \\
\hline $\begin{array}{l}{ }^{*} \text { Mother-Child Hospital, Institute of Social Security of the State of } \mathrm{N} \\
{ }^{*} \text { With regard to total events. }\end{array}$ & Muni & , Toluca, Dece & Novembe & & & 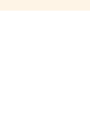 \\
\hline
\end{tabular}


Table 7. Cost of the care of pediatric patients with hemophilia * $^{*}$

\begin{tabular}{|c|c|c|c|c|c|}
\hline & $\begin{array}{l}\text { Total cost in the } \\
\text { study period } \\
\text { (\$ MXN) }\end{array}$ & $\begin{array}{l}\text { Cost per patient in the } \\
\text { study period ( } \$ \mathrm{MXN})\end{array}$ & $\begin{array}{l}\text { Annual cost } \\
\text { (\$ MXN) }\end{array}$ & $\begin{array}{l}\text { Annual cost per } \\
\text { patient ( } \$ M X N)\end{array}$ & \\
\hline $\begin{array}{l}\text { Without inhibitors }(n=19) \\
\text { Medical appointments } \\
\text { Laboratory tests } \\
\text { Imaging studies }\end{array}$ & $\begin{array}{l}28767.9 \\
13565.0 \\
27453.0\end{array}$ & $\begin{array}{l}1514.1 \\
713.9 \\
1444.9\end{array}$ & $\begin{array}{l}14384.0 \\
6782.5 \\
13726.5\end{array}$ & $\begin{array}{l}757.1 \\
357.0 \\
722.4\end{array}$ & $\begin{array}{l}0.06 \\
0.03 \\
0.05\end{array}$ \\
\hline $\begin{array}{l}\text { Factor VIII } \\
\text { Prophylaxis } \\
\text { Hemorrhagic events }\end{array}$ & $\begin{array}{c}43367156.0 \\
7138337.6\end{array}$ & $\begin{array}{c}2282481.9 \\
375702.0\end{array}$ & $\begin{array}{c}21683578.0 \\
3569168.8\end{array}$ & $\begin{array}{c}1141240.9 \\
187851.0\end{array}$ & $\begin{array}{l}85 . \overline{52} \\
14 . \overline{0.8}\end{array}$ \\
\hline $\begin{array}{l}\text { Factor VII } \\
\text { Prophylaxis } \\
\text { Hemorrhagic events }\end{array}$ & $\begin{array}{l}0.0 \\
0.0\end{array}$ & $\begin{array}{l}0.0 \\
0.0\end{array}$ & $\begin{array}{l}0.0 \\
0.0\end{array}$ & $\begin{array}{l}0.0 \\
0.0\end{array}$ & 0.00 \\
\hline Visit to the emergency department & 14911.0 & 784.8 & 7455.5 & 392.4 & \\
\hline Hospitalization & 58936.8 & 3101.9 & 29468.4 & 1551.0 & $0.12 \underline{\underline{n}}$ \\
\hline Indirect costs & 58923.0 & 3101.2 & 29461.5 & 1550.6 & \\
\hline Total & 50708050.3 & 2668844.8 & 25354025.2 & 1334422.4 & \\
\hline $\begin{array}{l}\text { With inhibitors }(n=5) \\
\text { Medical appointments } \\
\text { Laboratory tests } \\
\text { Imaging studies }\end{array}$ & $\begin{array}{c}5479.6 \\
4589.0 \\
25441.0\end{array}$ & $\begin{array}{c}1095.9 \\
263.6 \\
1339.0\end{array}$ & $\begin{array}{c}2739.8 \\
2294.5 \\
12720.5\end{array}$ & $\begin{array}{l}548.0 \\
131.8 \\
669.5\end{array}$ & 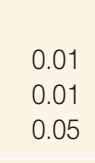 \\
\hline $\begin{array}{l}\text { Factor VIII } \\
\text { Prophylaxis } \\
\text { Hemorrhagic events }\end{array}$ & $\begin{array}{c}17833751.7 \\
374220.0\end{array}$ & $\begin{array}{c}3566750.3 \\
74844.0\end{array}$ & $\begin{array}{c}8916875.9 \\
187110.0\end{array}$ & $\begin{array}{c}1783375.2 \\
37422.0\end{array}$ & $\frac{32.12}{0.6 \frac{12}{5}}$ \\
\hline $\begin{array}{l}\text { Factor VII } \\
\text { Prophylaxis } \\
\text { Hemorrhagic events }\end{array}$ & $\begin{array}{l}11614136.8 \\
25601054.3\end{array}$ & $\begin{array}{l}2322827.4 \\
5120210.9\end{array}$ & $\begin{array}{c}5807068.4 \\
12800527.2\end{array}$ & $\begin{array}{l}1161413.7 \\
2560105.4\end{array}$ & $\begin{array}{l}20 . \frac{\bar{c}}{92} \\
46.17\end{array}$ \\
\hline Visit to the emergency department & 4836.0 & 967.2 & 2418.0 & 483.6 & \\
\hline Hospitalization & 42864.1 & 8572.8 & 21432.0 & 4286.4 & \\
\hline Indirect costs & 12517.3 & 658.8 & 6258.7 & 329.4 & \\
\hline Total & 55518889.9 & 11097530.0 & 27759444.9 & 5548765.0 & 100.00 \\
\hline \multicolumn{6}{|c|}{$\begin{array}{l}\text { *Mother-Child Hospital, Institute of Social Security of the State of Mexico and Municipalities, Toluca, December } 2015 \text { to November } 2017 . \\
{ }_{*}^{*} \text { Annual cost percentage per patient. \$ MXN = Mexican pesos. }\end{array}$} \\
\hline
\end{tabular}

absenteeism in the group without inhibitors was $\$ 1,550.6$ ( $0.12 \%$ of total annual cost per patient), in comparison with \$329.4 (0.02\%) in the group with inhibitors.

\section{Total costs}

Estimated total cost for the care of patients with hemophilia A during the study period was $\$ 106,226,940.2$, with an annual cost of $\$ 53,113,470.1$ for all 24 included patients, which represented a cost of $\$ 13,766,374.7$ per patient for the entire study period and an average annual cost per patient of $\$ 6,883,187.4$. Annual cost per patient in the group without inhibitors was $\$ 1,334,422.4$ in comparison with $\$ 5,548,765.0$ in the group with inhibitors, wbich represents a cost 4.2 times higher in the group with inhibitors. As observed in Table 7, more than $95 \%$ of annual cost depended on the use of coagulation factors (factors VIII and VII), mainly for prophyläxis (\$61,200,907.8 throughout the study period for factor VIII and $\$ 11,614,136.8$ for factor VII), but also forthe treatment of hemorrhagic events, and it was different between both subgroups, with $99.6 \%$ for the use of factor VIII in the subgroup without inhibitors, in comparison with $32.8 \%$ in the group with inhibitors. ${ }_{10}$ owever, the cost in the group with inhibitors for the wse of factor VII corresponded to $67 \%$ of annual costeper patient, while in the group without inhibitors it was not required. 


\section{Discussion}

In this study, hemophilia A was found to be associated with high levels of morbidity, in addition to having an important economic impact, which increases 4.2 times in the presence of inhibitors. All potential sources of cost in hemophilia A were included and were described in detail (medical appointments, laboratory or imaging studies, care of hemorrhagic events, indirect costs, etc.) for a holistic analysis of the economic impact of hemophilia (type A, since no cases of hemophilia $B$ were recorded) and of the presence of inhibitors in a pediatric population.

This research is a continuation of the academic work that our group has developed with regard to the costs of hemophilia in Mexico. ${ }^{9}$ The cost analysis showed that more than $95 \%$ of costs depend on the use of coagulation factors, which is consistent with the findings reported by multiple international publications $^{8-10}$ It is important pointing out that most patients (> $90 \%$ ) received hemostatic factors for the treatment of the disease, and a considerable percentage of them, prophylactic treatment. This suggests that, in Mexico, in spite of economic limitations, carrying out treatment protocols similar to those recommended by the World Federation of Hemophilia and the Mexican Clinical Practice Guidelines for the Diagnosis and Treatment of Hemophilia in the Pediatric Population is being sought. ${ }^{11,12}$ These interventions have a substantial impact with regard to a decrease in the frequency of hemorrhagic events and in associated morbidity, as well as to long-term disability. ${ }^{13,14}$ This study also showed a high frequency of bleeding in the mucous membranes, which might be related to low reporting of this type of bleeding, given its low impact on patient morbidity.

Given the elevated costs of treatment with coagulation factors, indirect costs would appear to be low $(0.02 \%$ of total cost); however, this can have considerable implications for the families of affected patients. The present study explores all potential sources of costs within the process of care of patients with hemophilia based on the review of individual medical records. Other analyses have tried to recreate an outlook of the repercussions and the economic impact with more subjective quantifications (surveys to specialists), ${ }_{11}^{11}$ but that contribute to a better understanding of the national impact of this disease.

This study has important limitations; for example, it corresponds to patients cared for in a single institution; notwithstanding, it provides valuable information, given that hemophilia continues to be a rare disease, in addition to characterizing in detail 24 pediatric cases, out of which approximately $20 \%$ developed inhibitors. The low number of cases also limited multivariate statistical approaches, which are essentia for determining independent associations, and thus, clinical conclusions are still limited.

Our research shows, from the perspective of a national public institution, that the development of inhibitors in the pediatric population with hemophilia $A$ substantially increases the costs of the disease.

\section{Acknowledgements}

The authors thank Novo Nordisk México S. A . de C.V. for the financial support required for the pefformance of this study and, in this regard, declare that they have no competing interest, other than having received the sponsorship. The study design, datacollection and analysis, as well as the writing of this document and its submission for publication were carried out with complete autonomy.

\section{References}

1. Gringeri A, Lundin B, von Mackensen S, Mantovani L, Mannucci PM, ESPRIT Study Group. A randomized clinical trial of prophylaxis in children with hemophilia A (the ESPRIT Study). J Thromb Haemost. 2011;9:700-710.

2. Qu Y, Nie X, Yang Z, Yin H, Pang Y, Dong P, et al. The prevalence of hemophilia in mainland China: a systematic review and meta-analysis. Southeast Asian J Trop Med Public Health. 2014;45:455-466.

3. Valentino LA, Hakobyan N, Enockson C, Simpson ML, Kakodkaß NC, Cong $\mathrm{L}$, et al. Exploring the biological basis of haemophilic joint disease: experimental studies. Haemophilia. 2012;18:310-318.

4. Ljung R, Gretenkort-Andersson N. The current status of prophylactic replacement therapy in children and adults with haemophilia. Br fHaematol. 2015;169:777-786.

5. Rocino A, Cortesi PA, Scalone L, Mantovani LG, Crea R, Gringeri A, et al. Immune tolerance induction in patients with haemophilia @ and inhibitors: effectiveness and cost analysis in an European Cohort(The ITER Study). Haemophilia. 2016;22:96-102.

6. Carlos-Rivera F, Gasca-Pineda R, Majluf-Cruz A, García-Chávez J.Economic impact of hemophilia type A and B in Mexico. Gac Med Mex.2016; 152:19-29.

7. Zhou ZY, Koerper MA, Johnson KA, Riske B, Baker JR, Ullman M, et al. Burden of illness: direct and indirect costs among persons with flemophilia A in the United States. J Med Econ. 2015;18:457-65.

8. Shrestha A, Eldar-Lissai A, Hou N, Lakdawalla DN, Batt K. Real-world resource use and costs of haemophilia A-related bleeding. Haemophilia. 2017;23(4):e267-e275.

9. Castillón-Benavides NK. Impacto económico del tratamiento de pacientes pediátricos con hemofilia tipo A en el Hospital Materno Infantil de ISSEMyM [tesis de posgrado]. México: Universidad Autónoma delEstado de México; 2016.

10. Gringeri A, Mantovani LG, Scalone L, Mannucci PM, COCIS Study Group. Cost of care and quality of life for patients with hemophilia comptigated by inhibitors: the COCIS Study Group. Blood. 2003;102:2358-2363.

11. Srivastava A, Brewer AK, Mauser-Bunschoten EP, Key NS, Kitchen S, Llinas A, et al. Guidelines for the management of hemophilia. Haemophilia. 2013;19:e1-e47.

12. Secretaría de Salud. Guía de práctica clínica. Diagnóstico y tratamientento de hemofilia en adultos. México: Secretaría de Salud; 2010.

13. Fernandes S, Carvalho M, Lopes M, Araújo F. Impact of an individualized prophylaxis approach on young adults with severe hemophilia. Semin Thromb Hemost. 2014:40:785-789.

14. Balkaransingh $P$, Young G. Novel therapies and current clinical progress in hemophilia A. Ther Adv Hematol. 2018;9:49-61. 